\title{
KECERDASAN LOGIS-MATEMATIS ANAK BERKEBUTUHAN KHUSUS (ABK) TUNARUNGU DALAM MENYELESAIKAN MASALAH MATEMATIKA
}

\author{
Galih Krisna Yoga ${ }^{1)}$, Siti Khoiriyah ${ }^{2)}$, Hidayatulloh ${ }^{3)}$. \\ 1) 2) ${ }^{3)}$ Universitas Muhammadiyah Pringsewu \\ galihkrisnay@gmail.com, ${ }^{2}$ sitikhoiriyah@umpri.ac.id \\ hidayatulloh@umpri.ac.id
}

\begin{abstract}
ABSTRAK
Hasil belajar matematika pada semester ganjil 2018-2019 masih relatif rendah. Penelitian ini dalam bentuk deskriptif, subjek dalam penelitian ini adalah siswa kelas VIII SLB Negeri Pingsewu tahun pelajaran 2018-2019. Instrumen yang digunakan adalah dalam bentuk soal tes berupa elaborasi pertanyaan dan pedoman wawancara. Berdasarkan hasil analisis data, dapat disimpulkan bahwa tingkat kecerdasan logis matematis anak berkebutuhan khusus (ABK) tuli dalam menyelesaikan masalah matematika berbeda-beda, Dari 3 siswa indikator tersebut mampu menghitung secara matematis masalah nomor 1 yaitu sebanyak (100\%), pada pertanyaan nomor 2 adalah (66,6\%), pertanyaan nomor 3 adalah (66,6\%), untuk pertanyaan nomor 4 adalah (100\%).
\end{abstract}

Kata kunci: hasil belajar, kecerdasan logis-matematis

\begin{abstract}
Mathematics learning outcomes in the odd semester of 2018-2019 are still relatively low. This research is in the form of descriptive, the subjects in this study are students of class VIII deaf SLB Pingsewu State school year 2018-2019. The instrument used was in the form of test questions in the form of question elaboration and interview guidelines. Based on the results of data analysis, it was concluded that the level of mathematical logical intelligence of children with special needs $(A B K)$ deaf in solving mathematical problems vary, Of the 3 students on the indicator is able to calculate mathematically problem number 1 that is as much as (100\%), on the questions number 2 is (66.6\%), question number 3 is (66.6\%), for question number 4 is $(100 \%)$.
\end{abstract}

Keywords: learning outcomes, logical-mathematical intelligence

\section{PENDAHULUAN}

Pendidikan merupakan pembelajaran pengetahuan, keterampilan dan kebiasaan sekelompok orang yang diturunkan dari generasi ke generasi berikutnya melalui pengajaran, pelatihan, atau penelitian. Pendidikan luar biasa merupakan layanan pendidikan yang khusus diberikan bagi peserta didik berkebutuhan khusus dengan tujuan agar mereka dapat melewati proses pertumbuhan dan perkembangan yang optimal, terutama dalam melaksanakan kegiatan belajar (Suningsih, 2017). Pendidikan ini merupakan awal yang sangat penting untuk seorang anak, karena melatih 
mereka untuk membaca dengan baik, mengasah kemampuan berhitung serta berfikir. Saat ini pendidikan di sekolah dapat ditempuh oleh siapapun dari berbagai kalangan dan golongan. Berbagai sekolah didirikan untuk menjadi tempat atau sarana pendidikan bagi anak tanpa terkecuali anakanak berkebutuhan khusus. Berbagai kurikulum juga di kembangkan untuk sekolah agar dapat membantu anak dalam proses pembelajaran yang baik dan bermutu.

Setiap anak, termasuk anak berkebutuhan khusus (ABK) merupakan amanah dan karunia Tuhan Yang Maha Esa yang dalam dirinya melekat harkat dan martabat sebagai manusia seutuhnya. Anak berkebutuhan khusus (ABK) merupakan anak yang memiliki kekurangan karena memiliki cacat fisik, mental, maupun sosial. Anak berkebutuhan khusus (ABK) memiliki hak yang sama dengan anak-anak normal lainnya dalam segala aspek kehidupan. Begitu pula dalam hal pendidikan mereka juga memiliki hak untuk bersekolah guna mendapat pengajaran dan pendidikan. Dengan memberikan kesempatan yang sama kepada anak berkebutuhan khusus (ABK) untuk memperoleh pendidikan dan pengajaran maka akan membantu mereka dalam membentuk kepribadian yang mendidik, mandiri, dan terampil. Keterlibatan pihak-pihak profesional bagi anak berkebutuhan khusus memiliki makna yang berarti bagi proses perlindungan dan tumbuh kembangnya. Oleh karena itu, pengetahuan dan peningkatan kapasitas pendamping, yaitu orang tua, keluarga, dan masyarakat, dalam menghadapi anak berkebutuhan khusus sejak dini akan memberikan dampak signifikan dalam merawat, memelihara, mendidik, dan meramu bakat atau potensi yang dimiliki setiap anak berkebutuhan khusus. Menurut Muhamad Irvan dan Dian Puspa Dewi (2018) dalam penelitiannya menemukan bahwa "Kesiapan dan kesiagaan orang tua dan keluarga yang memiliki anak berkebutuhan khusus merupakan kunci sukses penanganan, ditambah dukungan dari masyarakat dan pemerintah dalam menyediakan lingkungan dan fasilitas yang ramah terhadap anak berkebutuhan khusus" Evilianida. (2010:12).

Setiap warga negara berhak mendapatkan pendidikan yang layak sebagaimana tercantum dalam UUD 1945 Pasal 31 ayat 1 bahwa tiap warga negara berhak mendapat pendidikan, termasuk warga negara yang memiliki kelainan fisik, mental, emosional, intelektual, dan sosial. Anak berkrbutuhan khsus (ABK) dalam pendidikan inklusi memperoleh pendidikan yang bermutu sesuai dengan kebutuhan dan kemampuannya sebagaimana yang tercantum dalam Permendiknas No 70 tahun 
2009 pasal 1 bahwa pendidikan inklusi memberikan kesempatan kepada semua peserta didik yang memiliki kelainan dan bakat yang istimewa untuk mengikuti pendidikan dalam suatu lingkungan pendidikan bersama dengan peserta didik pada umumnya. Pendidikan inklusi itu sendiri adalah sistem layanan pendidikan yang mengatur agar difabel dapat dilayani kekolah terdekat, di kelas regular bersamasama teman seusianya, tampa harus dikhususkan kelasnya, siswa dapat belajar bersama dengan aksesibilitasnya yang mendukung untuk semua siswa tanpa terkecuali difabel. Dengan demikian, anak yang memiliki kebutuhan khusus dapat belajar bersama-sama dengan anak yang normal. Faktor lain yang dapat mempengaruhi prestasi belajar matematika peserta didik adalah cara seseorang individu mengingat, membuat persepsi dan memperolehi kembali maklumat. Ia juga menerangkan bagaimana seseorang individu memperoleh pengetahuan (kognisi) dan bagaimana mereka memproses pengetahuan tersebut (konseptual) (Suningsih, 2015). Hal tersebut berkaitan erat dengan kecerdasan logis matematis.

Kecerdasan logis matematis adalah kemampuan dalam menggunakan angka dengan baik, melakukan penalaran dengan benar, mengolah alur pikiran yang panjang dan mencerna pola-pola logis atau numeris dengan benar. Kecerdasan yang satu ini merupakan kecerdasan yang dimiliki para ilmuwan, akuntan, dan pemrogram komputer. Orang dengan gaya belajar ini cenderung sistematis dan sangat memerhatikan prosedur. Mereka membenci orang-orang yang tidak mengikuti aturan ataupun prosedur yang sudah dibuat. Saat bekerja, mereka pun harus melihat gambaran besarnya terlebih dahulu sebelum melakukan.

Untuk dapat mengenali seorang anak memiliki kecerdasan logis matematis yang tinggi, berikut ini ciri-cirinya:

\section{Memiliki kemampuan dalam penalaran atau analisa yang kuat dan kritis}

Anak juga memiliki kemampuan untuk mengurutkan, berpikir dalam pola sebabakibat, menciptakan hipotesis, mencari keteraturan konseptual atau pola numerik, dan pandangan hidupnya umumnya bersifat rasional.

Cenderung akan mengeluarkan banyak pertanyaan dari mulutnya, melakukan analisis, mencari bukti-bukti serta menyelesaikan masalah

\section{Banyak bertanya tentang cara kerja suatu hal}

Anak dengan kecerdasan logis matematis yang tinggi memiliki kepekaan akan segala sesuatu yang terjadi di sekitarnya.

\section{Menyukai permainan strategi dan matematika}

Anak dengan kecerdasan logis matematis yang baik biasanya menyukai permainan 
atau game yang berhubungan dengan strategi dan angka atau matematika, seperti permainan sudoku.

\section{Suka memecahkan teka-teki}

Lihatlah, apakah anak mama dapat duduk berjam-jam untuk memecahkan teka-teki dalam suatu permainan? Jika ya, itu tandanya anak mama memiliki kecerdasan logis matematis yang baik.

\section{Menyukai cerita-cerita detektif}

Anak akan bertanya-tanya kepada orangtuanya siapa pelakunya sambil menebak-nebak atau bertanya tentang kelanjutan ceritanya.

\section{Sangat menyukai pelajaran matematika} dan sains

Pelajaran matematika dan sains bukan lagi menjadi pelajaran yang menakutkan bagi anak dengan kecerdasan matematis tinggi, malah sebaliknya anak akan sangat suka dan menikmati pelajaran tersebut.

Mereka cenderung unggul di antara temantemannya dalam pelajaran ini.

\section{Sangat tertarik dengan komputer}

Biasanya anak suka dengan game-game strategi, juga suka dengan berbagai macam program sulit misalnya adalah pascalemrograman.

\section{Suka bereksperimen}

Hal ini dikarenakan anak memiliki rasa ingin tahu yang tinggi sehingga anak pun senang melakukan eksperimen-eksperimen untuk memenuhi rasa penasarannya.
Meskipun demikian, kita sebagai orangtua memiliki kewajiban untuk memberikan pendampingan pada anak ketika ia melakukan eksperimen-eksperimen dengan tujuan untuk menghindarkan anak dari sesuatu atau kecelakaan yang tidak diinginkan.

Tentu saja pendampingan yang diberikan bukan untuk menghalangi atau terlalu ikut campur, tetapi dengan memberikan penjelasan yang berkaitan dengan yang ia kerjakan.

Misalnya, memberikan penjelasan atau makna sebab akibat dari yang dilakukan anak.

\section{Memiliki nilai yang lebih tinggi dalam pelajaran sains dan matematika}

Anak-anak dengan kecerdasan logis matematis yang baik akan mempunyai skor atau nilai yang bagus di sekolah, terutama pada pelajaran sains, IPA, dan matematika.

Dengan kata lain anak yang memiliki kecerdasan logis matematis tinggi cenderung memiliki sifat cerdas, kreatif, dinamis, inovatif, mandiri, kritis, komunikatif, disiplin, dan tanggung jawab (Suningsih, 2016).

\section{METODE PENELITIAN}

Penelitian ini berlokasi di SLB Negeri Pringsewu, J1 Makam KH. Gholib Pringsewu, Kecamatan Pringsewu Barat, Kabupaten Pringsewu, Provinsi Lampung. 
SLB Negeri Pringsewu terdiri dari tiga jenjang yaitu SD, SMP, dan SMA.

Informan pada penelitian ini adalah siswa siswi SLB Negeri Pringsewu. Khususnya kelas VIII yang memiliki kekurangan pada pendengaran (tunarungu) dan berjumlah 3 orang siswa

\section{Teknik dan Alat Pengumpulan Data}

Wawancara dilakukan untuk menemukan permasalahan mengenai proses siswa dalam memecahkan masalah yang telah diberikan oleh peneliti. Wawancara adalah metode yang berupa pertanyaan dari peneliti langsung kepada siswa untuk memperkuat bukti terkait permasalahan yang dialami siswa-siswi dalam memecahkan masalah. Pedo]

wawancara digunakan sebagai acuan peneliti dalam mengumpulkan data. Data hasil wawancara digunakan peneliti untuk meninjau apakah hasil yang diperoleh dari hasil tes tertulis akan memberikan hasil yang sama dengan hasil yang diperoleh dari hasil wawancara, selain itu juga untuk mengungkap data yang tidak terlihat dari hasil tes. Sehingga data yang diperoleh merupakan hasil yang sebenarnya. Setiap pertanyaan yang dibuat untuk wawancara disesuaikan dengan kecerdasan logismatematis. Ragam pertanyaan dapat berubah sesuai dengan jawaban siswa dan memuat permasalahan yang sama dengan pertanyaan yang diajukan secara tertulis.
Instrument ini dibuat sendiri oleh peneliti maka perlu dilakukian uji validitas (validitas isi).

\section{HASIL DAN PEMBAHASAN}

Kecerdasan logis-matematis adalah salah satu dari delapan jenis kecerdasan manusia yang dikemukakan oleh Howard Gardner seorang profesor psikologi di Harvard University dalam teorinya tentang kecerdasan ganda (multiple intelligence) yang dikembangkan selama lima belas tahun terakhir. Kecerdasan logis-matematis adalah kemampuan seseorang dalam berfikir secara induktif dan deduktif, berfikir menurut aturan logika, memahami dan meganalisis pola angka-angka, serta memecahkan masalah dengan menggunakan kemampuan berfikir.

Kecerdasan logis matematis merupakan kemampuan dalam berhitung, mengukur dan mempertimbangkan proporsisi dan hipotesis, serta menyelesaikan oprasi-oprasi angka-angka. Angka adalah simbol bilangan. Kumpulan dan deret angka, atau simbol pada bilangan, disebut matematika. Siswa seperti ini cendenrung menyukai aktifitas berhitung dan memiliki kecepatan tinggi dalam menyelesaikan permasalahan. Menurut Seto Mulyadi (2014:85) Kecerdasan logis-matematis melibatkan banyak komponen yaitu: perhitungan secara 
matematis, berfikir logis dan nalar, secara matematis, dimana pada saat pemecahan masalah.

Anak-anak berkebutuhan khusus menyelesaikan soal siswa dapat melakukan merupakan anak anak yang memiliki keunikan tersendiri dalam jenis kebutuhan dan karakteristiknya yang membedakan dari anak-anak normal pada umumnya. Pada Undang-Undang RI No. 2 tahun 1989 tentang sistem pendidikan nasional ditegaskan bahwa anak atau peserta didik yang yang memiliki kelainan fisik dan mental disebut dengan istilah anak luar biasa. Sementara dalam undang-undang RI No.20 tahub 2003 tentang sistem pendidikan nasional anak yang memiliki kelainan fisik dan mental disebut dengan istilah anak berkebutuhan khusus (Wiyani, 2016:17). Dalam Wikipedia anak berkebutuhan khusus adalah anak dengan kepemilikan karakteristik khusus berbeda dengan anak lain pada umumnya tanpa selalu menunjukan pada ketidak mampuan mental, emosi, atau fisik. Penyandang tunanetra, tunarungu, tunagrahita, tunadaksa, tunalaras, kesulitan belajar ganguan prilaku, anak berbakat dan anak dengan ganguan kesehatan masuk dalam kategori anak berkebutuhan khusus.

Analisis kecerdasan logis-matematis siswa didasarkan pada jawaban siswa dari hasil tes dan wawancara. Kecerdasan logismatematis siswa dilihat berdasarkan 3 indikator meliputi : 1) mampu menghitung operasi hitung dengan benar dan tepat. 2) mampu berpikir logis dan nalar, dimana pada saat penarikan kesimpulan siswa menggunakan fakta-fakta yang ada dan menggunakan rumus yang sesuai untuk mendapatkan kesimpulan yang benar. 3) mampu memecahkan masalah, siswa dinyatakan mampu memecahkan masalah apabila dalam menyelesaikan soal siswa dapat menggunakan langkah-langkah pemecahan masalah dengan benar.

Hasil analisis data disimpulkan bahwa dari 3 orang siswa yang mampu menghitung secara matematis untuk soal nomor 1 yaitu seluruh siswa (100\%) mampu berhitung secara matematis, pada soal nomor 2 terdapat 2 orang siswa $(66,6 \%)$, untuk soal nomor 3 terdapat 2 orang siswa $(66,6 \%)$ dan untuk soal nomor 4 yaitu seluruh siswa (100\%) yang mampu benghitung secara matematis. Dalam menghitung secara matematis yang perlu diperhatikan yaitu bagaimana siswa dapat melakukan operasi hitung dengan benar. Pada indikator mampu berhitung secara matematis 1 orang siswa pada nomor 2 dan 3 tidak mampu dalam berhitung secara matematis. Ketidak ketercapaian siswa pada indikator berhitung secara matematis ini kemungkinan siswa tidak mampu dalam melakukan operasi hitung yang terdapat didalam soal. Untuk 
soal nomor 1 dan 4 siswa mampu berhitung secara matematis karena perhitungannya meliputi operasi penjumalahan dan 1 operasi perkalian. Tetapi untuk soal nomor 2 dan 3 kemungkinan siswa tidak mampu dalam menghitung matematis dikarenakan operasi hitung yang terdapat dinomor 2 dan 3 tergolong sulit yaitu operasi bagi dan 2 operasi perkalian. Kemungkinan dalam pembelajaran sehari-hari guru terbiasa memberikan soal dengan 1 operasi hitung saja atau soal masih tergolong mudah. Dengan demikian untuk mengurangi kesalahan tersebut dalam memyelesaikan soal siswa harus sering berlatih berhitung mengerjakan soal-soal latihan karena dengan berlatih berhitung dapat meningkatkan ketrampilan berhitung siswa Chatib (2014:21).

Hasil analisis data disimpulkan bahwa dari 3 orang siswa yang mampu berpikir logis dan nalar untuk soal nomor 1 terdapat 3 orang siswa (100\%), pada soal nomor 2 terdapat 2 orang siswa $(66,6 \%)$, untuk soal nomor 3 terdapat 2 orang siswa $(66,6 \%)$ dan untuk soal nomor 4 seluruh siswa (0\%) tidak mampu mencapai indikator berpikir logis dan nalar. Dalam berfikir logis dan nalar yang perlu diperhatikan yaitu apa yang diketahui dari soal dan dalam menyelesaikan soal siswa memilih rumus yang sesuai. Untuk soal nomor 2 dan 3 satu orang siswa yang tidak mampu dalm berfikir logis dan nalar, dan untuk soal nomor 4 seluruh siswa tidak mampu berfikir logis dan nalar. Ketidak ketercapaian siswa dalam indikator mampu berfikir logis dan nalar untuk nomor 2 dan 3 ini kemungkinan karena siswa tidak paham dengan konsep volume bangun ruang dan mengukur panjang sehingga siswa tidak tahu rumus apa yang akan dia gunakan dalam menyelesaikan soal yang diberikan. sedangkan untuk nomor 4 siswa tidak memahami konsep sudut. Dari hasil pengamatan peneliti, guru masiH sering menuntun siswa dalam mengerjakan soal. Sehingga hal yang terjadi adalah siswa tidak mandiri dalam mengerejakan soal. Jika hal ini yang terjadi maka sebaiknya guru harus sering melatih nalar siswa dengan memberikan soal yang dapat melatih nalar siswa dan siswa seharusnya melakukan analisis terhadap soal-soal sehingga dapat melatih nalarnya, banyak berlatih mengerjakan soal-soal serta menuliskan apa yang diketahui dalam soal sehingga siswa dapat menghitung dengan baik dan sesuai hasil yang diinginkan serta guru perlu membiasakan murit untuk mengerjakan soal-soal sendiri dengan demikian dapat melatih kemandirian siswa Asrul (2011:23).

\section{SIMPULAN}

Berdasarkan hasil analisis yang tersaji pada bab IV diperoleh kesimpulan bahwa tingkat kecerdasan logis-matematis anak 
berkebutuhan khusus (ABK) tunarungu dalam menyelesaikan masalah matematika berbeda-beda. Dari 3 orang siswa pada indikator mampu dalam menghitung secara matematis soal nomor 1 terdapat 3 orang siswa (100\%) mampu dalam berhitung secara matematis, pada soal nomor 2 terdapat 2 orang siswa $(66,6 \%)$ dan soal nomor 3 terdapat 2 orang siswa $(66,6 \%)$ mampu berhitung secara matematis, serta untuk soal nomor 4 seluruh siswa (100\%) yang mampu mecapai indikator menghitung secara matematis. Pada indikator mampu berpikir logis dan nalar dari 3 orang siswa untuk soal nomor 1 seluruh siswa (100\%) mampu berpikir logis dan nalar, pada soal nomor 2 terdapat 2 orang siswa $(66,6 \%)$ dan nomor 3 terdapat 2 orang siswa $(66,6 \%)$ mampu berpikir logis dan nalar, dan untuk soal nomor 4 terdapat 0 orang siswa $(0 \%)$ mampu berfikir logis dan nalar. Pada indikator mampu memecahkan masalah dari 3 orang siswa untuk nomor 1 seluruh siswa (100\%) mampu memecahkan masalah, pada soal nomor 2 terdapat 2 orang siswa $(66,6 \%)$ dan nomor 3 terdapat 2 orang siswa $(66,6 \%)$ mampu memecahkan masalah, dan untuk soal nomor 4 terdapat 0 orang siswa (0\%) mampu memecahkan masalah.

\section{DAFTAR PUSTAKA}

Asrul (2011)."Penemuan Metode Penemuan Terbimbing Dalam Pembelajaran Matematika Untuk Meningkatkan
Pemahaman Konsepdan Kemampuan Berfikir Kritis Siswa Sekolah Dasar" edisi khusus nomor, 1, Agustus 2011

Chatib (2014). Sekolahnya Manusia. Bandung : PT. MizanPustaka

Evilianida. (2010).” Pemecahan Masalah matematika", jurnal visipena 1 (2), 10-17

Muhamad Irvan dan Dian Puspa Dewi. (2018). Kajian Penanganan Terhadap Anak Berkebutuhan Khusus". e-ISSN : 2622 - 5719, P - ISSN : 2622 - 5700

Seto Mulyadi. (2014). Sekolah Anak-Anak Juara. Bandung :Kaifa

Suningsih, Y. A. (2017). Komunikasi Matematis Siswa Tunarungu Melalui Model Pembelajaran Think Pair Share. Aksioma, 6(3), 375-384.

Suningsih, A. (2015). Pembelajaran Garis Lurus Dengan Model Eliciting Activities Dan Team Assisted Individualization Ditinjau Dari Gaya Kognitif. E-DuMath, 1(1), 30-42.

Suningsih, A. (2016). Pembelajaran Matematika Menggunakan Think Talk Write Ditinjau Dari Kecerdasan Logika Matematika. E-DuMath, 2(1), 66-77.

Wiyani. (2016). Buku Ajar Penanganan Anak Usia Dini Berkebutuhan Khusus. Yogyakarta: AR-RUZZ MEDIA. 